Наташа М. Милојевић

Универзитет у Крагујевцу

Филолошко-уметнички факултет

Студент докторских студија
УДК: 821.111(71)-31.09 Атвуд М. https://doi.org/10.18485/uzdanica.2020.17.2.12

Оригинални научни рад Примљен: 30. септембар 2020. Прихваћен: 11. децембар 2020.

\title{
НАРАЦИЈА, ТРАДИЦИЈА И МАНИПУЛАЦИЈА: МИТ О ПОСТАҢУ У ТРИЛОГИЈИ БЕСНИАДАМ МАРГАРЕТ АТВУД
}

$A \bar{u} c \bar{u} p a \kappa \bar{u}:$ Девастирана и разорена цивилизација у коју Маргарет Атвуд смешта своје протагонисте чини се да жуди за поновном изградњом у виду реконструисаних библијских митова. Употребом пародије и гротеске, али и смештањем библијског мита о постању, метафоре јединства и кохерентности, у средиште нарације, трилогија БесниАgaм готово да упућује на испитивање у постмодернистичком кључу. Анализа поменутих романа у светлу постмодернистичких постулата о неутемељености сазнања има за циљ да укаже на то да свака потрага за значењем хуманог али и постхуманог идентитета у роману, која се нужно окончава у наративу, упућује на немогућност његовог досезања. Митске конструкције на којима протагонисти теже да конституишу своје идентитете су илузорне, чиме се и идентитет потврђује као наративна структура чије се коначно формирање вечно одлаже. Иако се испредање приче о причи открива као средство разоткривања манипулативног и вечно субјективног творења нарације, оно истовремено доводи у питање могућност критичког разоткривања које није истовремено и сопствено откривање, будући да је и прича која нам истину проглашава наративна конструкција.

Кључне речи: мит, постмодернизам, идентитет, наратив, Маргарет Атвуд, БесниAgaм.

\section{УВОД}

Ако је циљ испредане приче у трилогији БесниАgaм да нас информише а не да забави, како нам то домишљато ауторка сигнализира кроз епиграф из Гуливерових ӣyйована, она нас већ, и не отпочињући причу, смешта у контекст у којем је причу важно промишљати. Како сваки вид људске активности уопште подразумева одређени почетак, мит о постању, будући да је већ отеловљен у наративном облику, доима се најподеснијом структуром за овакав подухват. 
Иако природа мита не дозвољава његово изједначавање са уметничким делима, митови уистину удахњују живот општим представама „у чулноконкретној форми” (Мелетински 1983: 9), они их опредмећују. Говорећи о миту као о предкњижевној форми, Мелетински му тако одузима оно својствено уметничким формама, попут стила и изражајних средстава, будући да може да искаже само оно „несвеснопесничко” (Мелетински 1983: 9). На трагу Аристотелове Поейике која mythos види као заплет, Нортроп Фрај изједначава наратив са митом, проналазећи у миту не само порекло књижевних форми, већ и у сваком наративу мит: „сви наративи су подједнако митови, онако како их ја видим, били истинити или не, било да су засновани на стварним догађајима или не"1 (Фрај 2007: 319).

Међутим, када се над наративом као упориштем знања, а тиме и над самом историјом као наративном конструкцијом, надвије свеопшта сумња, такозване метанарације постају средиште рециклирања у виду преиспитивања, пародирања и деконструисања у духу постмодернистичке поетике. Мит којим се књижевност од својих зачетака служила зарад постизања одређених уметничких циљева (Мелетински 1983: 9), али и његова употреба у оквиру много касније модернистичке ремитологизације, доживљава извесни преображај у постмодернистичкој тенденцији ревидирања и пародирања. Пратећи постулате постмодернистичке теорије, неизбежно је поимати мит, а посебно библијски мит као централизовану структуру чији је онтолошки статус неопходно преиспитати, а отуда се књижевност, као изданак самог мита, већ својом структуром намеће као најподеснији темељ за овакав подухват.

Књижевни опус Маргарет Атвуд, будући да из неисцрпне традиције позајмљује како фолклорне елементе попут легенди, бајки и митова, тако и енциклопедијске фрагменте и исечке из новина, готово да самом својом формом позива на разматрање у духу постмодернистичких теорија. Уисти-

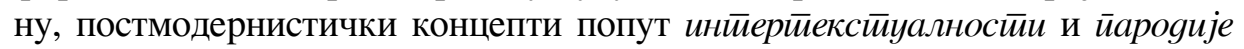
доимају се готово неодвојивим од рефабулације и поновног оживљавања традиционалних а каткад и савремених форми који се одигравају у склопу њених приповести. Прошлост, „инкорпорисана и модификована, добивши нов и различит живот и значење” (Хачн 1996: 52), конституише се као фундамент грађења новог света, девастираног и разореног под налетом глобалне пандемије у трилогији БесниАgaм. Митска матрица отуда у романима постаје средство конституисања сопства, али и придавања значења пољуљаном непрепознатљивом свету. Мит као наративни облик јасно се приказује као конструкт, будући да нам сваки од романа трилогије предочава процес митотворења, док се готово паралелно одвија домишљато испредање приче о причи, или постмодернистичким дискурсом речено - једна метанарација.

\footnotetext{
${ }^{1}$ Све наводе са енглеског језика превела је ауторка рада.
} 
Упркос сложеној (ре)конструкцији митова чије се порекло може изнаћи у различитим митологијама, библијски мит о постању бива смештен у средиште наратива, како због гротескног инсистирања припадника нове врсте на његовој реитерацији, тако и због конституисања њиховог онтолошког идентитета на темељима ове реконструкције. Међутим, управо опредмећивање јединства, кохеренције и реда (Фрај 1982: 112) које би мит о постању требало да подразумева, чини га идеалном метом за деконструкцију како у хуманом, тако и у постхуманом контексту.

Смештајући своје протагонисте у вртлог нераскидивих веза са великим традиционалним наративима, Атвудова им даје способност да на темељима заоставштине конструишу властите ревидиране верзије наратива у складу са сопственим побудама. Међутим, конституишући властите центре у оквиру центра који је и сам фабрикована наративна творевина, намеће се не само питање стаоилности било каквог значења већ и идентитета који се, извирући из наратива, открива као дубоко нестабилан и илузоран.

\section{ХУМАНИЗАМ (НИ)ЈЕ МРТАВ?}

Трилогија која отпочиње романом Орикс и Крејк већ у уводном делу читаоцу предочава „нулти сат” (Атвуд 2004: 3), у којем је савремени технолошки свет апсолутно потчињен и девастиран, у сенци бујајуће природе. Џими, наизглед последњи човек на планети који би овој трансформацији могао да посведочи, иако истовремено суочен са сопственом трауматизованом свешћу, преузима улогу истовременог педагога, пророка и доброћудног ујака (Атвуд 2004: 7) како би осигурао не само опстанак Крејкове деце већ и свој сопствени.

Пратећи хронологију Џимијевих сећања, читаоци дознају да је узрок девастације смртоносни вирус домишљато упакован у пропаганду о рајској пилули која, између осталих бенефита, обећава и необуздану сексуалну енергију ономе ко се подвргне њеној употреби. Творац чудотворне пилуле, Џимијев пријатељ из детињства - Крејк, упоредо са спровођењем плана о деструкцији људске врсте креира и нову врсту, бића конципирана генетским инжењерингом чија је егзистенција лишена свега што Крејк сматра инхерентно људским недостацима.

Ове резултанте биотехнолошког инжењеринга, Крејкова деца, будући да своје бивствовање отпочињу унутар вештачки креираног комплекса, у тренутку напуштања комплекса у изузетној мери зависе од јединог преосталог дишућег артефакта прошлости, Џимија.

На траговима прошлости и бетонским рушевинама старог света отпочиње мрежа митског обрасца. Тамо где стари свет престаје да постоји, мит даје прве знаке живота. Наиме, упркос Крејковој првобитној замисли једног 
изразито постхуманог света чије су тежње за сазнањем о сопственом пореклу елиминисане током саме конструкције, Крејкова деца ипак инхерентно људски вапе за одговорима на питања Ко смо? Ogaкле ӣойичемо?. Отуда Џими, попут стожера прошлости, заузима позицију свезнања, а будући да постоји извесна апорија у умовима Крејкове деце када је реч о референцама на стари, технолошки напредни свет, ревидира наративну заоставштину прошлости креирајући стога један постхумани мит.

Упућени на Џимија, Крејкери одговоре на своја онтолошка питања добијају у виду ревидиране верзије библијског мита о постању. Џими, отуда, растрзан између сопствене неснађености у високотехнолошком свету прошлости, фрагмената наративне заоставштине и апсолутне неупућености Крејкове деце у свет који је сада иза њих, конструише ову ревидирану верзију мита као једину инстанцу уклопљиву у овај врли нови свет. Ишчекујући одговоре на питања, Крејкова деца формирају полукруг, док стрпљиво чекају да Џими поједе рибу коју претходно готово ритуално жртвују како би им заузврат уделио причу. Причу о почетку Џими започиње визуелном дескрипцијом хаоса који превазилази границе имагинације Крејкера. Хаос који Џими припаја својој приповести заправо упућује на период пре епидемије смртоносног вируса, период који уобличен језиком мита говори о људској грамзивости и сопственој аутодеструкцији.

Суочен са детерминисаношћу нове врсте да упозна своје порекло, Џими који своје постојање у новом свету и даље управља према фрагментарном згаришту света који то више није, наратив изналази у књижевној традицији, односно библијском миту о потопу. Међутим, библијски фрагмент „Господ је видео да човек чини велико зло на земљи и да је свака мисао његовог срца усмерена ка злу" (Пост. 6, 5) у ревидираној форми човека лишава одговорности за деструкцију која следи. Наиме, говорећи о условима који претходе постању Крејкера, Џими напомиње да су „људи у хаосу били и сами пуни хаоса, и хаос их је наводио на лоше ствари” (Атвуд 2004: 103).

Ум Крејкера, још увек неформиран у цивилизацијском смислу, прихвата Џимијев наратив и тиме ревидирани мит добија своју пуну форму. Јолес (2000: 73) мит дефинише као облик који претпоставља стварање света језиком. Отуда ова ревидирана верзија библијског мита удахњује живот постхуманом свету, креирајући тако не само референтну стварност којом се нова бића управљају, већ и срж њихове егзистенције и онтологије. Наиме, Џими у својим рукама ипак држи конце наратива који Крејкере дефинише. Међутим, иако је ревидирани библијски мит о потопу инстанца која конструише стварност новог света, он заправо под површином рефлектује тријумф претходно потлаченог хуманизма. Иако Крејкери своје постојање заправо дугују чудовишном напретку науке и биогенетског инжењеринга, доминантама старог света, Џимијева борб́ за хуманизам помоћу концепције ревидираног мита узима превласт над извитопереношћу науке која га је претходно деградирала. 
Књижевна традиција, односно фрагментарни остаци библијских митова јесу оно што у новом свету наместо науке конструише свест али и свет.

Безнадежни очај са којим се Џими суочава након што достиже свест о девалвираном стању претходно цивилизованог света, упућује га на трагање за смислом у рушевинама. Нулти сат којим роман отпочиње, али и завршава и одсуство званичног времена, упућују на један вид непојмљивог концепта времена и на потоњу неспособност протагонисте да свом постојању након апокалипсе припише значење. Суочен са прошлошћу које више нема, безизлазном садашњошћу али и будућношћу коју не назире, упућен је на конструкцију наратива како би свом бивствовању приписао смисао.

Међутим, Џимија преплављују фрагментарни остаци прошлих нараци$\mathrm{ja}$, речи непрекидно и изненада навиру, опседајући му мисли. „Разводњавање значења" (Атвуд 2004: 39), фразе чије порекло не може да утврди, упућују Џимија на помисао да је некада био ерудита. Управо ово разводњавање великих наратива, у чијим је оквирима Џими конституисао сопствену личност, упућује на постмодернистичко оспоравање јединствених хомогених система, стога фрагментарне фразе у његовом уму доживљавају расипање и немогућност припајања у целину. Жудња за ревидирањем прошлости, где је и даље смештена његова кривица због почињеног убиства, парадоксално навире у виду фрагментарних исечака енциклопедијских списа, психолошке литературе или застарелих речи, упућујући на недоступну прошлост. „Прошлост се може спознати искључиво кроз њене текстове" (Хачн 1988: 16) - импликација је Џимијеве запоседнутости управо текстом. Међутим, Џимијева првобитна немогућност да уједини фрагментарне исечке текстова у тотализовану целину извесна је критика хуманистичком наивном уверењу у опстанак центра, који заједно са девастираним човечанством можда више не стоји чврсто.

Ипак, како хумана тежња за истином о почетку која обитава у умовима Крејкера нагони Џимија на конструкцију наратива, он производи одређени вид кохерентног наратива. Библијски мит о постању у новом постхуманом контексту бива оживљен у готово пародијском кључу. Наиме, објашњавајући њихово порекло, Џими наводи да су кости Крејкера конструисане од корала, а њихово месо вуче корене из манга (Атвуд 2001: 102). Форма пародије, која истовремено укључује али и преиспитује оно што пародира (Хачн 1988: 11), доживљава свој пуни облик управо произашавши из свести ерудите и окорелог бранитеља традиције који је своје студентске дане проводио у бележењу и спасавању застарелих речи. Управо на тај начин, библијски мит о постању бива двоструко пародиран у роману.

Метанарација, на коју се Џими истовремено ослања али је и пародира, наставља свој живот у постхуманом свету, чиме упућује на истовремену зависност од структуре која се доводи у питање. Управо њен пародирани облик наставља да постоји као онтолошка одредница постхуманом идентитету. Креирање поретка уз помоћ пародиране верзије метанарације импликује 
разоткривање ове потребе за поретком, чиме постаје евидентно да су пореци на које се ослањамо ништа друго до људске конструкције (Хачн 1996: 80).

Ако човек својим рођењем бива смештен in medias res, a смисао изналази управо у облику нарација, чији почеци и крајеви успешно приписују значење његовом животу (Кермод 2000: 11), инсистирање постхуманог идентитета на причи о пореклу доима се парадоксалним. Људска тежња за извесним редом и значењем која свој потпуни облик добија у нарацији бива отуда транспонована на постхумани идентитет. Приписујући им људске квалитете и истовремену тежњу за тотализујућим наративом као носиоцем врховног смисла, ауторка креира идентитете који транспонују хуманистичку тежњу за јединством на постхумани свет. Међутим, како је прича о пореклу пародија, фабрикована метанарација, уједињујући центар се открива као фикција, чиме израњају управо нетотализујуће структуре (Хачн 1988: 58). Хуманистичка жудња за центром, макар се он доимао фиктивним, наставља свој живот у постхуманом управо да би у духу постмодернистичких тенденција центар наставио да буде непрестано оспораван, злоупотребљаван, али и противуречно неизбежан. Неизбежност великих нарација манифестује се тако кроз употребу пародије која истовремено велике библијске митове деконструише, али и увек изнова реконструише. „Чак и када се руга, пародија оснажује: формално речено, она приписује себи конвенције које извргава руглу, гарантујући тако њихово потоње постојање” (Хачн 2000: 75).

\section{БОЖЈИ ВРТЛАРИ - (ЗЛО)УПОТРЕБА МИТА}

Друга књига трилогије - Гоgина йойойа предочава читаоцу перспективу двеју жена, претходних припадница религиозног еко-култа Божји вр-

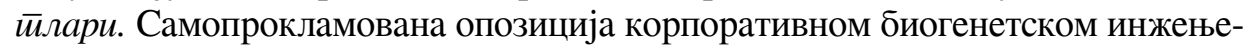
рингу, ова организација упоредо са узгојем хране и рециклажом истовремено настоји да обједини две културе. Наиме, покушај Божјих вртлара „да помире науку и хуманизам” Канаван (2012: 154) сагледава као њихов ултимативни пројекат. Управо се имплементацијом биолошких принципа у библијске митове рађају проповеди чија сврсисходност упућује не само на могућност еколошког освешћивања, већ и на последично обнављање биосфере.

Адам Први, оснивач култа, упоредо са реинтерпретацијом и модификовањем библијских митова, реконструише и еденски врт на крову зграде унутар које вртлари обитавају, наденувши му симболично име Рајска клисура. У складу са еколошком освешћеношћу, превасходна намена симболичне клисуре јесте да, наспрам генетски модификоване хране са могућим хуманим садржајем, цивилизацији понуди производе органског порекла. Међутим, органска храна која се становницима продаје неретко представља само остатке онога од чије су употребе вртлари одустали, или је каткад реч о спретно 
прерађеним сапунима који воде порекло из контејнера хотела и ресторана. Иако би се извесне противуречности у опхођењу и проповедима Божјих вртлара могле приписати управо еколошкој освешћености и бризи поводом интензивне и незаустављиве декаденције животне средине, противуречност се ипак ту не зауставља.

Наиме, на предстојећу катастрофу коју Крејк зналачки конструише Адам Први благовремено упозорава своје следбенике, инкорпорирајући је у ревидирани облик библијског мита, али и спретно таложећи залихе намирница како би чланови еко-култа били снабдевени у случају доласка Судњег дана. Као изричити противници конзумирања намирница животињског порекла, чланови ове организације упућују на незамисливе последице које вребају целокупно човечанство које се усудило „да изда поверење животиња” (Атвуд 2013: 63). Поистовећујући поборнике свог култа са Нојем, Адам Први упозорава на неизбежни потоп који ће истребити човечанство. У тренутку када истребљење животиња достиже несамерљиве размере, док конзумеризам не престаје да буја, једноставно је утврдити порекло апокалиптичних замисли вође култа. Међутим, необичност његових провиђења не огледа се само у пародијском кључу интерпретирања библијског мита, већ и у израженој прецизности његових предсказања. Наиме, Адам Први своје вернике подсећа на важност личне хигијене која досеже чак избегавање контакта са сваким ко показује симптоме прехладе. Потоп који пристиже „на крилима Божјих мрачних анђела” (Атвуд 2013: 110) готово да представља симболичну прераду Крејкових настојања да вирус садржан у пилули распрши широм планете уз несебичну помоћ своје једине љубави, „мрачног анђела” Орикс.

Након што пандемија наступи, једна од претходних припадница култа, Тоби, убрзо изналази аналогију између дешавања којима сведочи и предсказања о којима је Адам Први ревносно говорио у проповедима:

Ово је потоп на који су Вртлари тако често упозоравали. Знаци су ту: путује ваздухом као ношен на крилима, разара градове попут пламена, распрострањујући заражену руљу, терор и касапљење (Атвуд 2013: 20).

Реконструкција прошлости, којој протагонисти трилогије тако често прибегавају, разоткрива умреженост одређених чланова Божјих вртлара и Крејка, креатора згаришта човечанства. Иако се наизглед чини да сусрети Пилар, једне од поборница еко-култа и Крејка имају сентименталну вредност, након њене смрти, пилуле за које се испоставља да представљају саставни елемент смртоносног Крејковог дизајна завршавају управо у Крејковим рукама. Наиме, након неколико година проведених под окриљем култа Пилар умире, а Адам Први, поштујући њену последњу жељу, пилуле доставља Крејку. Неизбежно је закључити да је Адам Први, један од највећих гласника предстојећег разарања човечанства, заправо саучесник у помору. 
Доима се необичним да заговорник очувања и истинског поштовања живих бића хладнокрвно преда потенцијално смртоносно оружје. Међутим, противуречности у самој конструкцији култа израњају на површину и отуда ремете призор привидне тежње за обнављањем биосфере. Упркос учесталим нападима на различите култове зарад спречавања тероризма, Божји вртлари вешто одолевају нападима Корпорације. Адам Први истиче да Корпорација у циљу очувања репутације никада неће покушати да истреби организацију која носи Божје име (Атвуд 2013: 58). Наведен неслагањима у тумачењима различитих библијских фрагмената која доводе до преиспитивања сврсисходности употребе теологије, Адам објашњава:

Већина људи не мари за друге врсте када дођу тешки тренуци. Једино за шта маре јесте следећи оброк, што је и природно: морамо јести да не бисмо умрли. Међутим, шта ако је Бог онај који мари? [...] Постоји казна и без Бога у причи, наравно. Али је у то тешко убедити људе. Уколико постоји казна, неопходан им је неко ко кажњава. Нико не воли бесмислене катастрофе (Атвуд 2014: 287).

Адам Први, осведочени пацифиста који истовремено призива али и изазива предстојећу пандемију, парадоксално тежи очувању божјих бића учествујући у њиховом разарању. Култ чијим се убеђењима и учењима протагонисткиње романа управљају, очитава се као вођин неопходан алиби. Сама конструкција култа и Бог као конститутивни елемент његовог назива заправо има за циљ да уруши сваку помисао да би безазлена, готово театрална група запоседнута очувањем животне средине могла представљати опасност по друштвени систем.

Пародијско ревидирање библијских митова, попут мултидимензионалног пада из Раја, као и измењене верзије савеза између Бога и човека, која према проповедима Божјих вртлара укључује и животиње, отуда се нуди као конститутиван елемент сценографије, вешто пројектоване зарад суббверзивних циљева.

Манипулативна употреба велике нарације, библијског мита у пародијском кључу, конструише се као продужена рука корпоративних сакривених тровања популације зарад материјалног просперитета. Иако се њихови циљеви каткад разилазе, Адам Први, којем добра дела служе искључиво како би прикривао недела (Атвуд 2014: 140), субверзивно учествује у организованом урушавању цивилизације, надилазећи чак и способности саме Корпорације. Међутим, Адамова следбеница која након пандемије дознаје да је Адам Први тај који је спорне пилуле доставио Крејку, чини се да ову спознају занемаруje, настављајући да се присећа готово гротескних проповеди и да истински поштује празнике и ритуале конституисане унутар култа.

Како је деконструкција библијских митова субверзивна, пародија се не манифестује више као „нужно зло” које би неизбежно реконструисало 
оно што разоткрива, већ постаје средство утемељавања. Бартова „немогућност живљења изван бесконачног текста" (1975: 36) постаје злоупотребљена у рукама Адама Првог, који са свешћу о људској потрази за онтолошким упориштем у наративу креира једну тотализујућу структуру, симулирањем рушења већ постојеће структуре.

Дубока проблематичност конструисаног култа се стога не задржава у границама вешто осмишљеног алибија, већ се огледа у наставку интеракције коју догма има са својим претходним верницима, чак и у девастираном постхуманом свету. Наиме, попут протагонисте претходног романа трилогије, Џимија, који се грчевито држи великих наратива како би осигурао своје онтолошко место у постхуманој атмосфери која се не чини погодном за човечанство, Рен и Тоби, мислећи да су можда једине преживеле припаднице људске врсте, не ослобађају се пракси Вртлара већ их инкорпорирају у сопствену борбу за опстанак. Чак и када се остаци цивилизације разводњавају, тотализујући дискурс једног еко-култа, Фукоове доктрине, истрајава, изнова се конституише, подсећајући на неурушиву способност манипулације језиком и митом. Упркос томе што бројне противречности и несклад израњају из њихових тумачења библијских митова, припадници култа не посвећују време преиспитујући догму, учени да „дела претходе веровању” (Атвуд 2013: 201).

Ако и пуко „замишљање једног система продубљује учешће у садашњем систему" (Фуко 1977: 230), а учења Божјих вртлара маскирају субверзивно саучесништво у трулом корпоративном систему, догма која преживљава чак и незапамћену катастрофу стамено стоји сведочећи о неурушивости система. Међутим, иако су системи артифицијелни, последице људских конструкција, они опстају управо захваљујући утешној идеји о суштинском значењу које прети да буде нарушено заједно са контаминираним човечанством. У инхерентно људској потрази за значењем, редом и утемељењем, сложени илузорни конструкти настављају да живе, а „митологија, као одсечена Орфејева глава, наставља да пева и када је мртва и када је далеко” (Јунг, Керењи 2007: 15).

\section{НАРАЦИЈА, ИСТОРИЈА, ФИКЦИЈА}

Трећа књига трилогије, БесниАgам, предочава нам поновни сусрет претходних припадника Божјих вртлара, али и расплет њихове коегзистенције са генетски модификованом врстом, Крејкерима. Убрзо по успостављању суживота са новом врстом, онтолошка питања нове врсте израњају на површину, а њихова вапећа жудња за нарацијом чини се неутаживом. Приповедни ритуал, који је претходно био у Џимијевим рукама, егзистира и у трећој књизи трилогије, стога част да Крејкерима конституише врли нови свет припада Тоби. Преузевши Џимијеву капу и ручни сат као саставне елементе церемо- 
није, Тоби конструише ревидиране верзије прошлости. Међутим, наративни елементи као одговор на вечно горућа питања Крејкера бивају предочени у роману двојако: читаоцима се првобитно предочава верзија одређених догађаја доживљених из перспективе протагониста, да би потом прича конструисана зарад наративног ритуала имала ревидирани облик, најчешће са срећним крајем. Пародирање митова се наставља и у последњем делу трилогије, међутим, за разлику од злоупотребе мита која се разоткрива у претходном роману, наратив који Тоби конструише има за циљ да утоли жеђ нове врсте за приповешћу чији су протагонисти управо њени припадници.

Проблематичност која се указује у (ре)конструкцији оиблијских наратива зарад привидне добробити Крејкера јесте у самом начину на који постхумани идентитети примају мит. Наиме, како Бахрави (2013: 258) примећује, Крејкери не само да јасно оцртавају један постхумани идентитет, већ се истовремено налазе и у извесном прехуманом стању, поредећи отуда њихова религијска убеђења са неандерталцем. Уистину, пратећи Елијадеове записе о архаичном човеку, указује се извесна аналогија између његових запажања и понашања Крејкера. Елијаде (1961: 44) наводи да је једно од примарних интересовања примитивног човека заправо питање његовог порекла. Крејкери, упркос већ наратизованој причи о пореклу и њиховом постанку у Јајету, жуде за поновним преслушавањем наратива, захтевајући да га чују изнова и изнова: „Када Тоби коначно заврши причу, наговарају је да прича опет и опет. Добацују, прекидају, допуњавају делове које је изоставила" (Атвуд 2014: 59).

Елијадеово (1961: 190) запажање о немогућности архаичног човека да разазнаје између историје и мита је можда једна од најевидентнијих карактеристика Крејкера. Наиме, уколико умове ових идентитета заиста поимамо у форми празне плоче, који тек у размени информација са преживелим људима проналазе одговоре на онтолошка питања којима се касније управљају, евидентно је да се са нарацијом, а отуда и митским обрасцем, сусрећу на једном специфичном нивоу који Рикер дефинише као „ниво наивности” (Рикер, Керни 1978: 114). Управо се Рикерова теза о наивности у роману манифестује уколико се осврнемо на Елијадеово поимање архаичног човека који не може да разазна између историје и мита. Наиме, пред сам завршетак романа, читаоци се сусрећу са једном формацијом под називом Књига, чији садржај упућује на предања и нарацију о постанку Крејкера. Међутим, митска матрица која гради ове наративе бива разливена бележењем свакодневних догађаја из живота Крејкера којима непосредно сведоче. Ако човек примитивног друштва реактуализацијом митова приближава себи своје богове, увођењем историјског времена у ову матрицу нарушава се митско време које је по својој природи сакрално време (Елијаде 2003: 138). Отуда ванвременска структура мита бива нарушена увођењем историјског времена, чиме бива подривен расцеп између мита и историје, уводећи једну општу сумњу у њихову разграниченост. 
Митови којима се Крејкери управљају, упркос ретким појединостима које су се одиста и догодиле, углавном бивају састављени од елемената који се читаоцима евидентно откривају као фикција. „Прича о два јајета и мишљењу” има за циљ да образложи чињеницу да Крејкери могу да се споразумевају са генетски модификованим свињама. Тоби отуда конструише наратив који захваљујући узрочно-последичном систему разјашњава одређене феномене Крејкерима. Наратив о „богињи” Орикс која је снела два јајета, једно из којег су се излегле животиње и друго које је садржало речи, а до којег су Крејкери веома брзо допрли заједно са генетски модификованим свињама, не само да проглашава своју фиктивност већ се и тенденциозно конституише као пародија митске матрице. Међутим, самом употребом пародије мит се изнова конструише, јер сам језик пародије који је двогласан „истовремено упућује и на себе и на оно што пародира” (Хачн 2000: 69).

Митови се намећу као јасно уметнути фиктивни елемент, ревидиране приче које се каткад испредају како би Крејкере одржавале кроткима (Атвуд 2014: 58). Међутим, како митови у Књизи, који су дакако фиктивни, долазе у додир са непосредним извештавањем о свакодневним догађајима који одражавају једно историјско време, а границе између митологије и историје овим поступком постају порозне, не упућује ли то на фиктивну природу историје?

Историја као људски конструкт текстуалне је природе, наводи Хачн (1996: 16), и отуда постмодернизам карактерише једна свеопшта сумња у постојање историјског знања као утемељеног. Процес конструисања историје је можда најочигледнији при завршетку романа, где Крејкер, пишући Књигу и говорећи о Тобиној смрти, нуди плејаду могућих исхода њеног нестанка:

Неки пак кажу да је отишла са Зебом и да је он у облику Медведа, и да је она исто у облику Медведа, и да је сада са њим. То је најбољи одговор јер је најсрећнији, и ја сам га записао. Записао сам и друге одговоре. Али су они написани ситнијим словима. (Атвуд 2014: 474)

Субјективност, коју кроз конституисање историје Крејкеров запис испољава, представља тако материјални доказ зачетка манипулисања чињеницама које би требало да дословно подражавају свакодневицу. Постављајући историју у контекст субјективног тумачења, овакав подвиг иманентно постмодернистички „оспорава основе сваке одређености (историју, субјективност, референцу)” (Хачн 1988: 106).

Дуб์инско оспоравање ма каквог извора знања продужава се не само уметањем фиктивних елемената у мит који, иако света прича, Крејкерима доиста пружа одређено упориште знања о себи, већ и непоузданошћу „историјских" чињеница које у мит улазе. Наиме, Тоби позајмљује елементе Зебовог живота како би конципирала причу о њему, имајући у виду да Крејкери у његовој личности проналазе готово надљудског хероја. Међутим, чињенице уметнуте у мит засноване су на Зебовој приповести о њима, отуда истиснуте 
из сећања и подложне трансформацији. Приповест као темељ за формирање приповести још једном се открива као нестабилно подножје да би се икако утемељило као извор знања. Парадоксално, у постхуманом свету она то и јесте, не сакривајући своју нестабилност, креира једну илузију уточишта у причи.

Ако стабилних извора знања нема, претакање овог знања у говор о њему упућује на двоструку неоснованост и нестабилност. Међутим, ако ни уметност ни историја не пружају сигурно уточиште, онда њихова деконструкција и разарање путем нарације која је увек и сама конструкција не само да их не уништава као чврсте ослонце, већ их увек поново реафирмише и реконструише. Порицањем путем наратива који је и сам провизоран укида се свака провизорност и непоуздани извори знања опстају њиховим поновним изграђивањем. Ако нарација изворе знања демаскира, чиме их злоупотребљава (Хачн 1988: 172), она то ипак чини тако што их употребљава. Уколико „наратор који нам говори о немогућности конституисања метафоре јесте и câм, или је то његов говор, метафора” (Де Ман 1979: 18), нарација која разоткрива непоузданост приповести увек је и сама непоуздана.

Хачнова тврди да се овај парадокс упиње да „подвуче сложене контрадикције унутар друштвено предодређеног модуса мишљења” (1988: 5), модуса који смо креирали сами. Сложени контрадикторни систем мишљења као људска конструкција последица је исконске потребе за значењем. Отуда „прича у причи”, а неисрпна и неутажива тежња за нарацијом као објашњењем онтолошког положаја постхуманог идентитета рефлексија је хуманог безнадежног порива за самопотврђивањем у једном егоцентричном, контрадикторном, али вечно опстајућем наративу.

\section{ЗАКЉУЧАК}

Првобитна апсолутна декаденција хуманизма, под налетом екстремног развоја науке у цивилизацији пре њеног урушења, бива надвладана развојем наратива на темељима митске матрице. Несавладива снага наратива, који постаје једини доступан артефакт прошлости, не само да представља место конституисања идентитета у дакако нестабилном свету, већ и готово да надвладава протагонисте формирајући се као централни ентитет.

Човек пре истребљења, као што је то случај са Божјим вртларима, манифестује једну тежњу да се досегне до еколошке освешћености и трансформације урушавањем једног тотализујућег дискурса, корпоративне хегемоније. Међутим, овај напор не само да се проказује као бесмислен, јер се пародирани митски наратив формира као центар унутар центра, већ је и двоструко фиктиван, реинтерпретиран и реконструисан како би послужио као вео који маскира напоре за уништењем људске врсте. Након што цивилизација нестаје, нарација се протагонистима доима јединим сигурним уточиштем јер, 
уистину, фрагментарна наративна заоставштина готово да једина успева да досегне статус неурушивости.

Међутим, пародијски однос према традиционалним наративима, најпре миту, указује се као вид наглашавања непоузданости која твори њихову срж, али и њихове неизбежности јер упућује на један бесконачан циклични процес митотворења. Постхумани али и хумани идентитети у девастираном свету творе једну илузију самопотврђивања у наративу, вапећи за изналажењем значења унутар приче. Тоби и Рен се на темељима митова и учења Божјих вртлара управљају, упркос њиховој парадоксалној и гротескној форми. Џими, који реконструише библијске митове подстакнут непресушним питањима Крејкера, настоји да се унутар њих и сам потврди, будући да они представљају једину опипљиву спону са његовим преапокалиптичним идентитетом. Крејкери, као амалгам истовремене постхуманости али и прехуманости, једино у наративу досежу до одговора на горућа питања о сопственом идентитету и значењу.

Међутим, док се одређени митови творе како би субверзивно манипулисали, други, засновани на „прерађеним” елементима претходних нарација протагониста који су инкорпорирани у ревидирану митску матрицу, упозоравају не само на безизлаз из наративног вртлога који се доима уточиштем већ и на немогућност конституисања стабилног идентитета на основу нарације која ће заувек остати необјективна хумана творевина. Уколико, према постмодернистичким постулатима, објективног знања нема јер је знање увек већ условљено наративом о њему, прича која ревидирањем, деконструкцијом и реконструкцијом митова има за циљ да нас информише о процесима који „скривају трагове означавајућих система који конституишу наш свет - односно, система које сами конструишемо као одговоре на сопствене потребе" (Хачн 1996: 13), и сама се проглашава делом тог система. Стога, уколико је циљ приче да нас, пратећи епиграф с почетка о немогућности досезања суштинског знања, заиста информише - она то ипак не може да учини а да не разоткрије сопствену субјективну природу која је твори, чиме сама свој проглас истовремено пориче.

Обећање кохерентности и утемељења у оквирима мита о почетку показује се неопходним, јер се на овом обећању темеље идентитети протагониста. Идентитет се тако конституише као инхерентно наративна структура, подложна идентичном пародирању, травестирању, деконструкцији и реконструкцији које трпи текст. Неутажива тежња за непрекидним испредањем приче фигурира стога као рефлексија немогућности самопотврђивања у једној неприродној структури, али и ода њеној неуништивости. Митотворење се отуда никада не завршава, а протагонисти, који илузорно утеху налазе у фабрикованој творевини која саму себе прича, остају заточеници једног бесконачног наратива који их тамничи док му се клањају. 


\section{ИЗВОРИ}

Атвуд (2004): M. Atwood, Oryx and Crake, New York: Anchor Books. Атвуд (2013): M. Atwood, The Year of the Flood, London: Virago Press. Атвуд (2014): M. Atwood, MaddAddam, London: Virago Press.

\section{ЛИТЕРАТУРА}

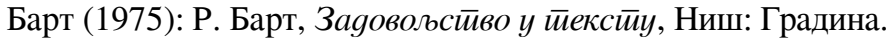

Бахрави (2013): N. Bahrawi, Hope of a hopeless world: ecoteleology in Margaret Atwood's Oryx and Crake and The Year of the Flood, Green Letters: Studies in Ecocriticism, vol 17:3, Philadelphia: Taylor \& Francis, Inc., 251-263.

Де Ман (1978): P. de Man, Allegories of Reading: Figural Language in Rousseau, Nietzsche, Rilke, and Proust, New Haven and London: Yale University Press.

Елијаде (1967): M. Eliade, Myths, dreams, and mysteries: the encounter between contemporary faiths and archaic realities, New York: Harper Collins.

Елијаде (2003): М. Елијаде, Свеӣо и йрофано, Нови Сад: Издавачка књижарница Зорана Стојановића.

Јолес (2000): A. Jolles, Jednostavni oblici, Zagreb: Matica hrvatska. Fedon.

Јунг, Керењи (2007): K. G. Jung, K. Kerenji, Uvod u suštinu mitologije, Beograd:

Канаван (2012): G. Canavan, Hope, But Not for Us: Ecological Science Fiction and the End of the World in Margaret Atwood's Oryx and Crake and The Year of the Flood, Literature Interpretation Theory, vol. 23, Philadelphia: Taylor \& Francis, Inc., 138-159.

Мелетински (1983): Е. М. Мелетински, Поейика мийа, Београд: Нолит.

Рикер, Керни (1978): P. Ricoeur, R. Kearney, Myth as the Bearer of Possible Worlds, The Crane Bag, Vol. 2, No. 1/2, 112-118.

Фpaj (1982): N. Frye, The Great Code, New York: Harcourt Brace Jovanovich.

Фpaj (2007): Northrop Frye's Fiction and Miscellaneous Writings, edited by R. D. Denham, M. Dolzani, Toronto: University of Toronto Press.

Фуко (1977): M. Foucault, Language, Counter-Memory, Practice, Ithaca, NY: Cornell University Press.

Хачн (1988): L. Hutcheon, A Postmodern Problematics, Ethics / Aesthetics: PostModern Positions, Robert Merrill ed., Washington DC: Maisonneuve Press. Svetovi.

Хачн (1996): L. Hačion, Poetika postmodernizma: istorija, teorija, fikcija, Novi Sad:

Хачн (2000): L. Hutcheon, A theory of parody: the teachings of twentieth-century art forms, Chicago: University of Illinois Press. 
Nataša M. Milojević

University of Kragujevac

Faculty of Philology and Arts

PhD student

\section{NARRATION, TRADITION AND MANUPULATION: CREATION MYTH IN MARGARET ATWOOD'S MADDADDAM TRILOGY}

Summary: Situated on the brinks of destroyed civilization, Margaret Atwood's protagonists seem to long for its restoration through the means of the reconstructed biblical myths. Employing parody and grotesque, while at the same time positioning the biblical myth of Creation in the center of the narrative as a metaphor for unity and coherence, MaddAddam trilogy implies its reading within the postmodernist framework. The analysis of the trilogy in reference to the postmodernist incredulity towards the concept of closed knowledge, serves to corroborate the claim that every quest for meaning implied by human as well as posthuman identities, culminates in the inaccessibility of the meaning due to its intricate narrative nature. Myth as grounds for identity formation proves to be illusory, leading to the perpetual postponing of the identity formation. Despite the fact that Atwood's unfolding of a story within a story implies the attempt to reveal the manipulation and subjectivity beyond the surface of the narrative, it also brings into question the possibility of any critical exposing which does not simultaneously expose itself, given that the story proclaiming the truth is a narrative as well.

Keywords: myth, postmodernism, identity, narrative, Margaret Atwood, MaddAddam. 